\title{
Constructions of logical expressions in analysis of vegetation transformations
}

\author{
Grażyna Laska \\ Department of Environmental Protection and Management, Białystok Technical University, Wiejska 45a, \\ 15-351 Białystok, Poland \\ e-mail: laska@pb.edu.pl
}

\begin{abstract}
The paper reports on the effects and range of anthropogenic pressure exerted on forest communities of the Knyszyńska Forest. A comparison between the potential natural vegetation and real vegetation gives an idea on the degree of damage to forest communities, which has been classified in ecological modelling. Logical expressions have been applied in ecological modelling for spatial analyses of vegetation changes carried out by the program ArcView GIS. The logical expressions applied to the GIS spatial database have permitted finding correlations of occurrence of particular types of the present-day real vegetation (in particular the post-clear-cutting communities, young tree communities and secondary forest communities) relative to the present-day potential natural vegetation. The data obtained in this way have been used in analysis of the scale and range of changes in the forest communities of the Knyszyńska Forest caused by forest management measures.

Results of the study have shown that in the Knyszyńska Forest, the secondary communities occupy as much as $88.3 \%\left(919.56 \mathrm{~km}^{2}\right)$, while the oldest tree-stands representing natural communities (of $100-120$ years of age) occupy only $11.7 \%\left(122.28 \mathrm{~km}^{2}\right)$. Among the secondary communities the greatest area is occupied by the secondary forest communities representing the stickstand and oldgrowth phases $(66.9 \%)$ aged from 30 to about 100 years. The contribution of young tree stands - aged from 10 to 30 years is smaller $-16.6 \%$, and that of post-clear-cutting and forest crops forming directly after clear cutting and aged up to 10 years is still smaller - of $4.8 \%$. In the young-tree stands (16.6\%) and forest secondary communities $(66.9 \%)$ the largest is the contribution of those with domination of pine trees (Pinus sylvestris) from artificial reforestation, making 11.2 and $55 \%$, respectively, while the contribution of other secondary communities is much lower.
\end{abstract}

Key words: N-E Poland, Knyszyńska Forest, GIS spatial database, potential natural vegetation, real vegetation, secondary communities, range of anthropogenic changes.

\section{Introduction}

Mathematical modelling in ecology mainly depends on the strategy and aim of research. Conceptually, the model constitutes a generic framework for testing and sorting out hypotheses on functioning processes involved in plants development (Berec 2002; Drouet \& Pagès 2003, 2007) or populations (Reed \& Levine 2005; Sakanoue 2007), communities (Reineking et al. 2006), ecosystems (Dambacher et al. 2003a, b) and landscapes (Lischke et al. 2006).

Ecological mathematical models, diverse in purpose and structure, are increasingly used to simplify the representations of reality. Early models were simple theoretical ones designed to produce general predictions unconstrained by the details of a particular time or place. These systems can be easily analytically described and solved (Fath 2004; Ulanowicz 2004; Fath et al. 2007). The growth of public interest in solving environmental problems has since provided a new impetus for the development of complex ecological models employing different methods such as numerical, artificial neural network (ANNs) and new software for ecological modelling, simulation and analysis (MVSP, Syntax, Statistica, EcoNet, ArcGis) (Jørgensen \& Bendoricchio 2001; Liu et al. 2003; Corne et al. 2004; Kazanci 2007; Scrinzi et al. 2007). The complex ecological models increased the range of problems of ecological research 
by the risk assessment of species (Li et al. 2000; Gevrey et al. 2006), biological conservation (Wintle et al. 2003), the quality of local and global change predictions (Jager \& King 2004), impact of climate changes (Fuentes et al. 2006), habitat sustainability and forest management (Van der Lee et al. 2006), biotic, abiotic and anthropogenic disturbances (Lundquist \& Sommerfeld 2002; Sturtevant et al. 2004a, b; Laughlin \& Grace 2006; Edgar \& Burk 2007; Laughlin \& Abella 2007; Tichit et al. 2007). For analysis of more complex correlations between different disturbing factors, in particular anthropogenic ones, the spatial modelling with the use of GIS procedures have been successfully applied (Nienartowicz \& Kunz 2001; McNeil et al. 2006).

This paper reports on the modelling made with the help of constructions of logical expressions to be used for analyses of spatial processes in vegetation in the program ArcView GIS (Esri 1993). The GIS method, which has been developing since 1960s, used for automatic mapping and modelling ecological systems, is extremely useful nowadays for transforming data and defining relationships between them (Gough \& Rushton 2000; Łaska \& Hildebrand 2001; Łaska 2006a). For many years different algorithms that could be used for identifying features such as structure of landscape, change of vegetation, characteristics of urban, degradation of soil, degeneration of forest, condition of forest etc., have been discussed. The aim of the study is to give an idea of the scale and range of changes in the forest communities of the Knyszyńska Forest performed on the basis of determination of correlations between the occurrence of particular types of the real vegetation with respect to the types of the potential natural vegetation, performed with the use of the logical expressions applied to the spatial GIS database. It is interesting to find why the pine tree stands dominate in the vertical structure of the majority of the forest communities despite a considerable presence of the potentially fertile oak-hornbeam habitats. The question is what are the reasons for the inconsistencies between the species composition and the types of habitats.

\section{The area and methods of study}

The idea of the study was prompted by the earlier field observations of changes in plant communities performed over 15 years (1987-2001) whose outcome was, among others, preparation of digital GIS databases for the forest communities in the Knyszynska Forest and their graphic presentation on 3 maps. The digital maps were prepared within the research project $(\mathrm{KBN}-\mathrm{nr} 6 \mathrm{P04G02812})$ realised in the years 1997-1999 (Laska 1999a, b, c, d, 2006b).

The study area was determined by the main forest complex mapped onto 12 sheets of the "Review Maps of State Forest Divisions" on the scale 1:25000, covering
12 forest districts included into 7 State Forest Divisions (Fig. 1). From the total area of the Knyszyńska Forest $1267.02 \mathrm{~km}^{2}$ (GUS 1999), only the State Forests area of $1094.634 \mathrm{~km}^{2}$, which makes $86.4 \%$ of the total area of the Knyszyńska Forest, was subjected to GIS analysis. The area is delimited between $52^{\circ} 55^{\prime} 47^{\prime \prime}$ and $53^{\circ} 42^{\prime} 10^{\prime \prime}$ of the north latitude and $22^{\circ} 52^{\prime} 20^{\prime \prime}$ and $23^{\circ} 54^{\prime} 22^{\prime \prime}$ ' east longitude. It was defined in the coordinates of the state reference system "Coordinate System 42".

\subsection{Processing and presentation of the information on the natural environment}

The processing of the environmental information was performed with the use of two digital spatial databases on the vegetation of the Knyszynska Forest, i.e. the present-day potential natural vegetation and the present-day real vegetation. The basic field units of the spatial database were defined as the spatial resultant of aggregation of forest subunits. The fundamental area unit of the spatial database was defined as spatial resultant of aggregation of forest subdistricts (forest taxation) belonging to the assumed categories of the potential and real vegetation. The exclusions were generalised to the level of the 1:25000 scale map detail.

In the informative datalayer each area was assigned with the system attributes of the surface database (PAT polygon attribute table) area, circumference, unique system number and user number. Besides the surface attribute table, each area was characterised by descriptive attributes specifying the type of the present-day potential natural vegetation (Rosp) and the present-day real vegetation (Rosr) to enable their processing in the computer system GIS. The descriptive but not spatial attributes were specified with the help of a coding system of vegetation units. In total, 9 categories of the present-day potential natural vegetation (Code Rosp) (Tab. 1) and 19 categories of the present-day real vegetation (Code Rosr) (Tab. 2) were distinguished.

\subsection{Computer system of GIS analysis}

The construction of logical expression was performed using the software GIS - ArcView version 3.0 (Esri 1993). The construction of a logical expression is used to formulate an exact logical question addressed to the database concerning the problem of interest. The logical inquiry to the database of vegetation attributes can comprise a number of attributes, operators and mathematical functions, and its construction should permit an effective and precise selection of the objects desired. The syntax is made most often with the chain type fields with the operators "and", "or" and "not". The operator "and" means that both logical expressions are true, "or" that at least one of them is true, 


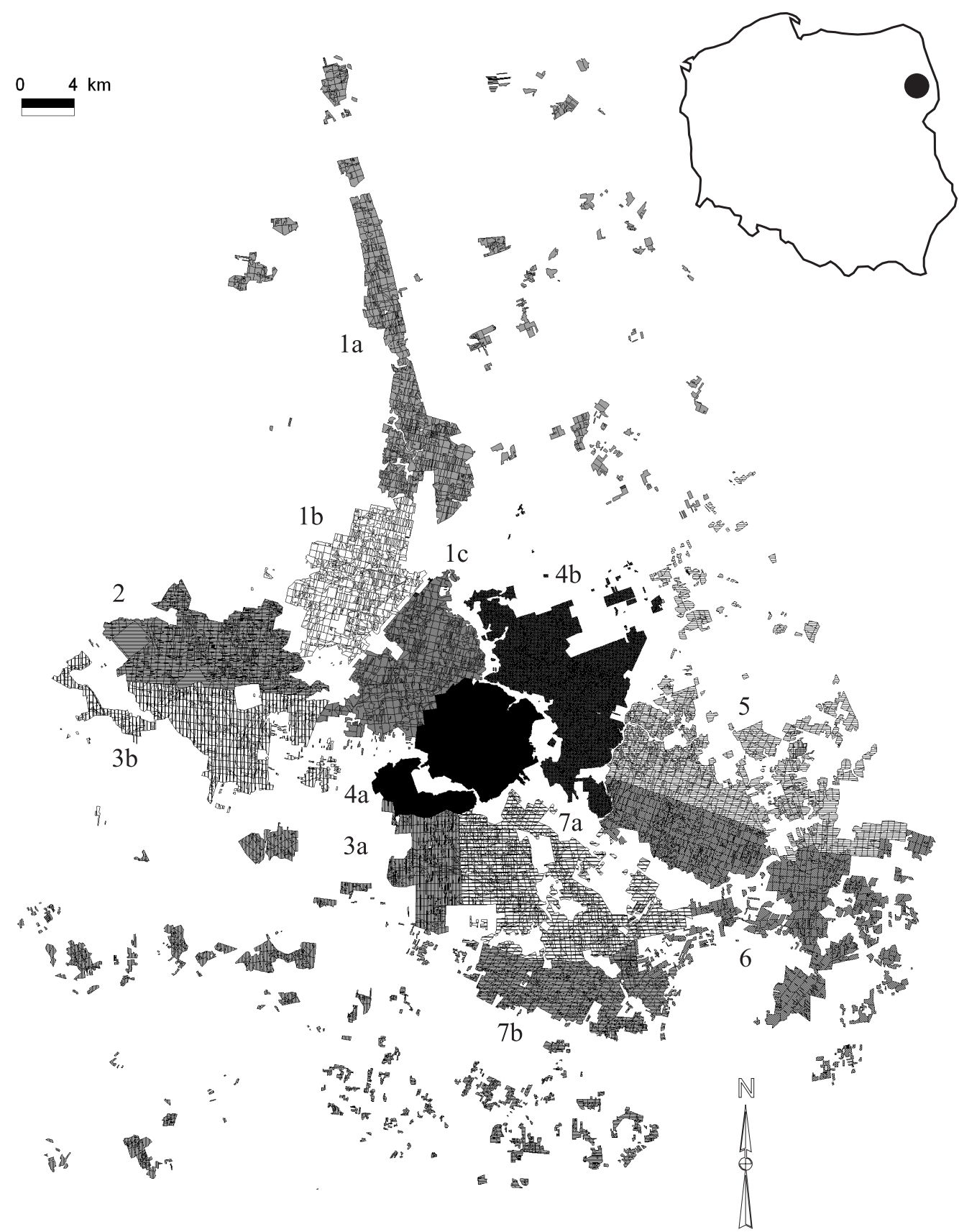

Figure 1. Localization and borders of the forest divisions and forest districts in the Knyszyńska Forest: 1 - Forest Division Czarna Białostocka, 1a - Forest District Kumiałka, 1b - Forest District Czarna Białostocka, 1c - Forest District Złota Wieś; 2 - Forest Division and Forest District Knyszyn; 3 - Forest Division Dojlidy, 3a - Forest District Dojlidy, 3b - Forest District Katrynka; 4 - Forest Division Supraśl, 4a - Forest District Supraśl, 4b - Forest District Sokółka; 5 - Forest Division and Forest District Krynki; 6 - Forest Division and Forest District Waliły; 7 - Forest Division Żednia, $7 \mathrm{a}-$ Forest District Zajma, $7 \mathrm{~b}$ - Forest District Żednia 
Table 1. Manner of coding of descriptive attributes of 9 categories of the present-day potential natural vegetation

\begin{tabular}{|c|c|c|}
\hline \multicolumn{3}{|c|}{ I Attribute - The present-day potential natural vegetation (Rosp) } \\
\hline Code & The name of distinguished vegetation units & The syntaxonomic names of communities \\
\hline 1 & $\begin{array}{l}\text { Subcontinental East-European pine forest } \\
\text { subboreal vicariant with spruce }\end{array}$ & Peucedano-Pinetum \\
\hline 2 & High coniferous forest & Carici digitatae-Piceetum \\
\hline 3 & Fresh mixed coniferous forest & Serratulo-Piceetum \\
\hline 4 & Thermophilous oak-hornbeam forest & Melitti-Carpinetum \\
\hline 5 & $\begin{array}{l}\text { Subcontinentale lowland linden-oak- } \\
\text { hornbeam forest; subboreal vicariant with } \\
\text { spruce }\end{array}$ & $\begin{array}{c}\text { Tilio-Carpinetum } \\
\text { (together with Acer platanoides-Tilia cordata) }\end{array}$ \\
\hline 6 & Wet mixed coniferous forest & $\begin{array}{c}\text { Querco-Piceetum } \\
\text { (together with Myceli-Piceetum) }\end{array}$ \\
\hline 7 & $\begin{array}{l}\text { Flood plain forests, bog forests, bog-spruce } \\
\text { and bog-pine forests }\end{array}$ & $\begin{array}{c}\text { Fraxino-Alnetum, Piceo-Alnetum, Ficario-Ulmetum, Carici elongatae- } \\
\text {-Alnetum, Thelypteri-Betuletum, Sphagno-Piceetum, Carici chordorrhizae- } \\
\text {-Pinetum, Vaccinio uliginosi-Pinetum, Ledo-Shagnetum }\end{array}$ \\
\hline 8 & Village areas within the Knyszyńska Forest & \\
\hline 11 & $\begin{array}{l}\text { Forests in the areas outside the compact } \\
\text { complex of the Knyszyńska Forest }\end{array}$ & \\
\hline
\end{tabular}

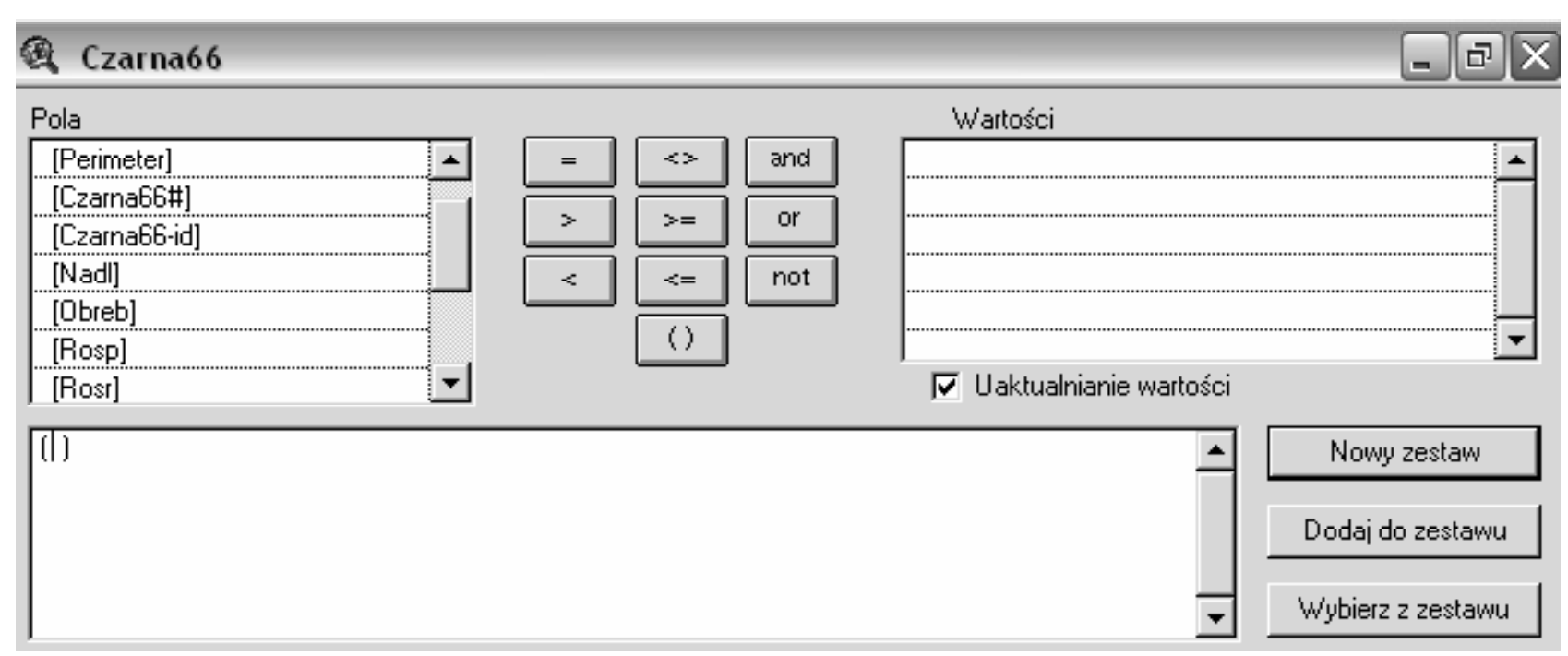

Figure 2. Constructor of logical expressions for determination of the correlation of occurrence of the present-day real vegetation (Rosr) against the units of the present-day potential natural vegetation (Rosp)

while "not" permits construction of mutually exclusive logical expressions (Fig. 2).

The syntax of the logical expression used in ArcView permitted a determination of the number of spatial objects satisfying the conditions of the logical expression $x=$ code Rosr and $y=$ code Rosp (Fig. 2). Thanks to this procedure of mapping the present-day real vegetation on the background of the present-day potential natural vegetation it was possible to get the information on the main cause of vegetation changes in the Knyszyńska Forest.

The method enabled statistical analyses of the presence and distribution of particular attributes distinguished in different datalayers. The results permitted calculation of the total and partial areas with the selected categories of the present-day potential natural and real vegetations over the whole area of the Knyszyńska Forest and in individual 
Table 2. Manner of coding of descriptive attributes of 19 categories of the real vegetation

\begin{tabular}{|c|l|}
\hline \multicolumn{2}{|l|}{ II Attribute - The real vegetation (Rosr) } \\
\hline Code & The name of distinguished vegetation units \\
\hline 1 & The post-clear-cutting and forest crops communities used of clear cutting \\
\hline 2 & The post-clear-cutting and forest crops communities used of partial cutting \\
\hline 3 & The natural forest communities \\
\hline \multicolumn{2}{|l}{ The young tree communities, including: } \\
\hline 4 & The young tree communities with domination of birch tree (Betula pendula) \\
\hline 5 & The young tree communities with domination of pine tree (Pinus sylvestris) \\
\hline 6 & The young tree communities with domination of spruce (Picea abies) \\
\hline 7 & The young tree communities with domination of oak (Quercus robur) \\
\hline 15 & The young tree communities with domination of alder (Alnus glutinosa) \\
\hline & \multicolumn{1}{c|}{ The secondary forest communities, including: } \\
\hline 8 & The secondary forest communities with domination of pine tree (Pinus sylvestris) \\
\hline 9 & The secondary forest communities with domination of spruce (Picea abies) \\
\hline 10 & The secondary forest communities with domination of birch tree (Betula pendula) \\
\hline 11 & The secondary forest communities with domination of oak (Quercus robur) \\
\hline 12 & The secondary forest communities with domination of hornbeam (Carpinus betulus) \\
\hline 13 & The secondary forest communities with domination of aspen (Populus tremula) \\
\hline 16 & The secondary forest communities with domination of alder (Alnus glutinosa) \\
\hline 17 & The secondary forest communities with domination of ash tree (Fraxinus excelsior) \\
\hline 19 & The secondary forest communities with domination of linden (Tilia cordata) \\
\hline 14 & The seminatural (meadows, pastures) and synanthropic (ruderals) communities \\
\hline 18 & Village areas within the Knyszyńska Forest \\
\hline
\end{tabular}

forest sections within its area. At the next step, a detail statistical analysis of the selected categories of vegetation of different types in the system of combination of their cooccurrence was performed. The database records satisfying the imposed logical expression were exported in the form of the Dbase files (*.dbf) to the calculation sheet in Microsoft Excel 2003 in which they were subjected to further statistical analysis (Tab. 3).

\section{Results}

\subsection{Present-day potential natural vegetation}

The results of the GIS analysis of 12 source maps have shown that the State Forest takes an area of $1094.63 \mathrm{~km}^{2}$, which makes $86.4 \%$ of the area of the Knyszyńska Forest. Of this area $24.4 \%\left(267.30 \mathrm{~km}^{2}\right)$ is taken by peripheral forests outside the compact complex of the Knyszyńska
Forest, $3.57 \%\left(38.91 \mathrm{~km}^{2}\right)$ is taken by villages and $72.03 \%$ $\left(788.42 \mathrm{~km}^{2}\right)$ is occupied by the distinguished types of the present-day potential natural vegetation. According to the syntaxonomic approach assumed after Czerwiński (1995) and Matuszkiewicz (2001), the following syntaxons have been identified (Tab. 4):

Association: Peucedano-Pinetum W. Mat. (1962) 1973

Association: Carici digitatae-Piceetum Czerw. 1978

Association: Serratulo-Piceetum Sokoł. 1968

Association: Melitti-Carpinetum Sokoł. 1971 em Czerw. 1978

Association: Tilio cordatae-Carpinetum betuli Tracz. 1962 (together with Acer platanoides-Tilia cordata Jutrz.Trzeb. 1993)

Association: Querco-Piceetum (W. Mat. 1952) W. Mat. et Pol. 1955 (together with Myceli-Piceetum Czerw. 1978)

Flood plain forests, bog forests, bog-spruce and bogpine forests (Fraxino-Alnetum W. Mat. 1952, Piceo-Alne- 
Table 3. Exemplary data exported from the ArcView program to the calculation sheet of Microsoft Excel, obtained taking into regard the logical expressions for the Forest Division Supraśl and Forest Districts Supraśl and Sokółka

\begin{tabular}{|c|c|c|c|c|c|c|c|c|}
\hline \multirow{3}{*}{ Logical expressions } & \multicolumn{8}{|c|}{ Forest Division Supraśl } \\
\hline & \multicolumn{4}{|c|}{ Forest District Sokółka } & \multicolumn{4}{|c|}{ Forest District Supraśl } \\
\hline & AREA & PER. & SOK66 & SOK66_ID & AREA & PER. & SUP66 & SUP66_ID \\
\hline \multirow[t]{3}{*}{1 Rosr - 1 Rosp } & & & & & 0.03786 & 0.93637 & 1455 & 1448 \\
\hline & & & & & 0.0347 & 0.97421 & 1464 & 1456 \\
\hline & & & & & 0.00553 & 0.29891 & 1702 & 1701 \\
\hline SUM TOTAL & & & & & 0.07809 & & & \\
\hline \multirow[t]{40}{*}{1 Rosr - 2 Rosp } & 0.00437 & 0.27511 & 258 & 257 & 0.05332 & 1.0466 & 38 & 40 \\
\hline & 0.01892 & 0.61836 & 281 & 282 & 0.0032 & 0.27819 & 46 & 47 \\
\hline & 0.01241 & 0.53973 & 288 & 289 & 0.00865 & 0.43505 & 106 & 110 \\
\hline & 0.01829 & 0.55616 & 322 & 327 & 0.01762 & 0.7981 & 121 & 120 \\
\hline & 0.01085 & 0.44387 & 356 & 365 & 0.02262 & 0.66912 & 130 & 134 \\
\hline & 0.06594 & 1.27687 & 368 & 378 & 0.0274 & 1.08031 & 137 & 148 \\
\hline & 0.02352 & 0.74942 & 385 & 393 & 0.02443 & 0.68575 & 188 & 193 \\
\hline & 0.00395 & 0.25458 & 401 & 407 & 0.01008 & 0.53232 & 193 & 197 \\
\hline & 0.01101 & 0.41731 & 523 & 535 & 0.01817 & 0.80637 & 318 & 325 \\
\hline & 0.00672 & 0.33069 & 556 & 552 & 0.01451 & 0.50344 & 440 & 446 \\
\hline & 0.00579 & 0.31533 & 566 & 560 & 0.0373 & 0.87639 & 569 & 577 \\
\hline & 0.03193 & 0.78033 & 575 & 583 & 0.00192 & 0.18059 & 1136 & 1123 \\
\hline & 0.00646 & 0.31855 & 580 & 593 & 0.06209 & 1.3182 & 1148 & 1147 \\
\hline & 0.0464 & 1.22549 & 585 & 591 & 0.01083 & 0.46199 & 1179 & 1167 \\
\hline & 0.01575 & 0.55604 & 628 & 621 & 0.01476 & 0.56831 & 1257 & 1259 \\
\hline & 0.04282 & 1.22062 & 629 & 634 & 0.05491 & 1.84115 & 1278 & 1267 \\
\hline & 0.00808 & 0.37103 & 675 & 679 & 0.04324 & 1.15565 & 1306 & 1312 \\
\hline & 0.03693 & 1.15236 & 709 & 708 & 0.01932 & 0.59845 & 1404 & 1406 \\
\hline & 0.01057 & 0.38978 & 727 & 715 & 0.01421 & 0.51659 & 1420 & 1405 \\
\hline & 0.02897 & 1.02261 & 742 & 755 & 0.01451 & 0.48985 & 1426 & 1412 \\
\hline & 0.02622 & 0.88074 & 743 & 721 & 0.00087 & 0.1213 & 1447 & 1450 \\
\hline & 0.00343 & 0.23822 & 747 & 752 & 0.0155 & 0.49545 & 1506 & 1501 \\
\hline & 0.04218 & 1.14799 & 754 & 732 & 0.01898 & 0.96015 & 1596 & 1593 \\
\hline & 0.04527 & 1.07666 & 767 & 772 & 0.00638 & 0.3413 & 1606 & 1605 \\
\hline & 0.00863 & 0.34279 & 777 & 780 & 0.01922 & 1.54356 & 1668 & 1669 \\
\hline & 0.0139 & 0.63823 & 811 & 803 & 0.04633 & 1.0949 & 1694 & 1693 \\
\hline & 0.05056 & 1.249 & 890 & 910 & & & & \\
\hline & 0.02264 & 1.06197 & 906 & 921 & & & & \\
\hline & 0.00883 & 0.3672 & 909 & 935 & & & & \\
\hline & 0.04526 & 1.07288 & 932 & 951 & & & & \\
\hline & 0.03782 & 1.28448 & 951 & 973 & & & & \\
\hline & 0.03296 & 1.14232 & 959 & 978 & & & & \\
\hline & 0.01418 & 0.6155 & 986 & 1003 & & & & \\
\hline & 0.02019 & 0.65717 & 994 & 1012 & & & & \\
\hline & 0.00634 & 0.32745 & 996 & 1017 & & & & \\
\hline & 0.00802 & 0.34599 & 1241 & 1267 & & & & \\
\hline & 0.04291 & 1.56043 & 1249 & 1275 & & & & \\
\hline & 0.09194 & 1.28479 & 1264 & 1291 & & & & \\
\hline & 0.07435 & 1.55894 & 1265 & 1292 & & & & \\
\hline & 0.08767 & 1.61837 & 1282 & 1309 & & & & \\
\hline SUM TOTAL & 1.0930 & & & & 0.58037 & & & \\
\hline
\end{tabular}




\begin{tabular}{|c|c|c|c|c|c|c|c|c|}
\hline \multirow{3}{*}{ Logical expressions } & \multicolumn{8}{|c|}{ Forest Division Supraśl } \\
\hline & \multicolumn{4}{|c|}{ Forest District Sokółka } & \multicolumn{4}{|c|}{ Forest District Supraśl } \\
\hline & AREA & PER. & SOK66 & SOK66_ID & AREA & PER. & SUP66 & SUP66_ID \\
\hline \multirow[t]{26}{*}{1 Rosr - 3 Rosp } & 0.0081 & 0.46065 & 31 & 31 & 0.00398 & 0.28743 & 207 & 209 \\
\hline & 0.0115 & 0.49522 & 137 & 117 & 0.03197 & 0.87623 & 213 & 219 \\
\hline & 0.03007 & 0.80356 & 225 & 229 & 0.00923 & 0.47419 & 284 & 293 \\
\hline & 0.01868 & 0.78271 & 342 & 342 & 0.03812 & 1.03344 & 293 & 289 \\
\hline & 0.0036 & 0.2625 & 538 & 582 & 0.02238 & 0.61707 & 310 & 310 \\
\hline & 0.02326 & 0.59686 & 548 & 570 & 0.02878 & 0.74821 & 366 & 379 \\
\hline & & & & & 0.04017 & 1.09975 & 396 & 402 \\
\hline & & & & & 0.02426 & 0.61712 & 522 & 526 \\
\hline & & & & & 0.01015 & 0.42761 & 547 & 551 \\
\hline & & & & & 0.05501 & 1.05944 & 652 & 645 \\
\hline & & & & & 0.01707 & 0.83748 & 670 & 670 \\
\hline & & & & & 0.00741 & 0.40822 & 1023 & 1015 \\
\hline & & & & & 0.00695 & 0.34832 & 1034 & 1047 \\
\hline & & & & & 0.00955 & 0.38611 & 1044 & 1059 \\
\hline & & & & & 0.00512 & 0.36912 & 1095 & 1097 \\
\hline & & & & & 0.03986 & 1.12243 & 1108 & 1116 \\
\hline & & & & & 0.00307 & 0.219 & 1137 & 1124 \\
\hline & & & & & 0.03644 & 1.35584 & 1159 & 1155 \\
\hline & & & & & 0.01026 & 0.46783 & 1203 & 1204 \\
\hline & & & & & 0.02519 & 0.89586 & 1303 & 1297 \\
\hline & & & & & 0.02892 & 0.78215 & 1346 & 1343 \\
\hline & & & & & 0.02096 & 0.60634 & 1384 & 1389 \\
\hline & & & & & 0.01709 & 0.537 & 1400 & 1410 \\
\hline & & & & & 0.04514 & 1.0878 & 1471 & 1463 \\
\hline & & & & & 0.00731 & 0.46496 & 1555 & 1555 \\
\hline & & & & & 0.00553 & 0.28887 & 1633 & 1634 \\
\hline \multirow[t]{2}{*}{ SUM TOTAL } & 0.09521 & & & & 0.54992 & & & \\
\hline & & & & & & & \multicolumn{2}{|c|}{ and continued... } \\
\hline
\end{tabular}

Legend:

Rosr - Present-day real vegetation

Rosp - Present-day potential natural vegetation

AREA - The forest area of polygon in $\mathrm{km}^{2}$

PER. - Perimeter of polygon

SOK66_, SUP66_- System number

SOK66_ID, SUP66_ID - User number

tum Sokoł. 1980, Ficario-Ulmetum minoris Knapp 1942 em. J. Mat. 1976, Carici elongate-Alnetum Koch 1926, Thelypteri-Betuletum Czerw. 1972, Carici chordorrhizaePinetum Pałcz. 1975, Sphagno girgensohnii-Piceetum Polak. 1962, Vaccinio uliginosi-Pinetum Kleist 1929).

The first six units represent the forest communities on the mineral soil taking $88.8 \%$ of the Forest area of which $58.9 \%$ are the forest communities in the coniferous forests habitats and $29.9 \%$ are the forest communities in the oakhornbeam habitats (Tab. 4). The last seventh unit represents the forest communities on hydrogenic soil, taking $11.2 \%$ of the Forest area, comprising flood plain forests, bog forests, bog-spruce and bog-pine forests, treated as one unit.

\subsection{Present-day real vegetation}

The term the present-day real vegetation refers to the actual vegetation in a given area whose state and composition reflect the current state of habitats and subjected to the impact of forest management. According to the spatial GIS analyses of the area of State Forests $1094.63 \mathrm{~km}^{2}$ the real vegetation occupies $1041.84 \mathrm{~km}^{2}$ (Tab. 5). The oldest tree-stands in the Knyszyńska Forest representing the natural and close to natural communities, of 100-120 years of age, make only $11.7 \%\left(122.28 \mathrm{~km}^{2}\right)$. The total area taken by the secondary communities including post-clear-cutting and forest crop communities, young tree communities and secondary forest communities is $919.56 \mathrm{~km}^{2}$, which makes $88.3 \%$ of the Knyszyńska Forest area (Tab. 5). Among the 
Table 4. The forest area $\left(\mathrm{km}^{2}\right)$ and percent contribution of the types of the present-day potential natural vegetation in the Knyszyńska Forest, in the area controlled by forest divisions and forest districts The area under state control, in this:

- the area taken by forest but outside the compact

$-1094.6340 \mathrm{~km}^{2}$

Knyszyńska Forest complex

- the area of villages

- types of the present-day potential natural vegetation

\begin{tabular}{|c|c|c|c|}
\hline \multirow[b]{2}{*}{ Code } & \multirow[b]{2}{*}{ Present-day potential natural vegetation } & \multicolumn{2}{|c|}{ Knyszyńska Forest } \\
\hline & & $\begin{array}{l}\text { The forest } \\
\text { area }\left[\mathrm{km}^{2}\right]^{*}\end{array}$ & $\begin{array}{c}\text { Percent contribution } \\
{[\%]^{* *}}\end{array}$ \\
\hline & a) Forest communities on mineral soils & 700.0035 & 88.8 \\
\hline 1 & $\begin{array}{l}\text { Subcontinental East-European pine forest } \\
\text { Peucedano-Pinetum }\end{array}$ & 93.9788 & 11.9 \\
\hline 2 & $\begin{array}{l}\text { High coniferous forest } \\
\text { Carici digitatate-Piceetum }\end{array}$ & 206.3705 & 26.2 \\
\hline 3 & $\begin{array}{l}\text { Fresh mixed coniferous forest } \\
\text { Serratulo-Piceetum }\end{array}$ & 112.5128 & 14.3 \\
\hline 4 & $\begin{array}{l}\text { Thermophilous oak-hornbeam forest } \\
\text { Melitti-Carpinetum }\end{array}$ & 77.3294 & 9.8 \\
\hline 5 & $\begin{array}{l}\text { Subcontinentale lowland linden-oak-hornbeam forest } \\
\text { Tilio-Carpinetum } \\
\text { (together with Acer platanoides-Tilia cordata) }\end{array}$ & 158.4779 & 20.1 \\
\hline 6 & $\begin{array}{l}\text { Wet mixed coniferous forest } \\
\text { Querco-Piceetum } \\
\text { (together with Myceli-Piceetum) }\end{array}$ & 51.3341 & 6.5 \\
\hline 7 & $\begin{array}{c}\text { b) Forest communities on hydrogenic soils } \\
\text { Fraxino-Alnetum, Piceo-Alnetum, Ficario-Ulmetum, Carici elongatae-Alnetum, } \\
\text { Thelypteri-Betuletum, Sphagno-Piceetum, Carici chordorrhizae-Pinetum, Vaccinio } \\
\text { uliginosi-Pinetum, Ledo-Sphagnetum }\end{array}$ & 88.4177 & 11.2 \\
\hline & TOTAL & 788.4212 & 100 \\
\hline
\end{tabular}

* The area of the compact Knyszyńska Forest complex, without the area taken by forest but outside the compact Knyszyńska Forest complex.

** Percent contribution in the area of the compact forest complex Area of forest units in $\mathrm{km}^{2}$ to the fourth place after comma, given for easy change of units to ha units.

secondary communities the greatest area is occupied by the secondary forest communities representing the stickstand and old-growth phases $(66.9 \%)$ in the age from 30 to about 100 years. The contribution of young tree stands - aged from 10 to 30 years is smaller $-16.6 \%$, and that of postclear-cutting and forest crops forming directly after clear cutting and aged up to 10 years is still smaller - of $4.8 \%$.

\subsection{Analyses of vegetation changes in terms of the spatial GIS data}

In the area of the Knyszyńska Forest, the secondary forest communities making $66.9 \%$ are mostly represented by those with dominant pine (Pinus sylvestris) (55\%) in the stickstand phase (Tab. 5). They have developed mainly from the young tree communities with artificially planted pine trees taken from plantations. The contribution of the secondary forest communities with domination of other species is very low. For example, the secondary forest communities with domination of oak (Quercus robur) make only $4.2 \%$, with domination of spruce (Picea abies) $-3.5 \%$, with domination of birch tree (Betula pendula) $-2.8 \%$ and with domination of alder (Alnus glutinosa) $-1.2 \%$ (Tab. 5).

In the young-tree stands $(16.6 \%)$ the largest is the contribution of those with domination of pine trees (Pinus sylvestris) from artificial reforestation, making $11.2 \%$, while the contribution of other young-tree communities is much 
Table 5. The forest area $\left(\mathrm{km}^{2}\right)$ and percent contribution of the types of real vegetation in the Knyszyńska Forest in the area controlled by forest divisions and forest districts

The total area of the Knyszyńska Forest

The area under state control, in this:

- seminatural communities (meadows, pastures)

$-1267.02 \mathrm{~km}^{2}(126702 \mathrm{ha})$

- synanthropic communities (segetal, ruderal)

$-1094.634 \mathrm{~km}^{2}$

- areas devoid of vegetation or unidentified

$-8.6081 \mathrm{~km}^{2}(0.8 \%)$

$-20.9422 \mathrm{~km}^{2}(1.9 \%)$

$-23.2450 \mathrm{~km}^{2}(2.1 \%)$

Total

$-52.7953 \mathrm{~km}^{2}(4.8 \%)$

Types of present-day real vegetation

$-1041.8386 \mathrm{~km}^{2}(95.2 \%)$

\begin{tabular}{|c|c|c|c|}
\hline Code & Present-day real vegetation & $\begin{array}{l}\text { The forest } \\
\text { area }\left[\mathrm{km}^{2}\right] *\end{array}$ & $\begin{array}{c}\text { Percent } \\
\text { contribution } \\
{[\%]^{* *}}\end{array}$ \\
\hline \multirow[t]{2}{*}{3} & The natural forest communities & 122.2834 & 11.7 \\
\hline & Non-forest and forest secondary communities: & 919.5552 & 88.3 \\
\hline 1 & The post-clear-cutting and forest crops communities used of clear cutting & 34.0176 & 3.3 \\
\hline \multirow[t]{2}{*}{2} & The post-clear-cutting and forest crops communities used of partial cutting & 15.8066 & 1.5 \\
\hline & The young tree communities, including: & 172.9709 & 16.6 \\
\hline 4 & - the young tree communities with domination of birch tree (Betula pendula) & 9.7908 & 1.0 \\
\hline 5 & - the young tree communities with domination of pine tree (Pinus sylvestris) & 117.0835 & 11.2 \\
\hline 6 & - the young tree communities with domination of spruce (Picea abies) & 24.2628 & 2.3 \\
\hline 7 & - the young tree communities with domination of oak (Quercus robur) & 18.9362 & 1.8 \\
\hline \multirow[t]{2}{*}{15} & - the young tree communities with domination of alder (Alnus glutinosa) & 2.8976 & 0.3 \\
\hline & The secondary forest communities, including: & 696.7601 & 66.9 \\
\hline 8 & - the secondary forest communities with domination of pine tree (Pinus sylvestris) & 572.3313 & 55.0 \\
\hline 9 & - the secondary forest communities with domination of spruce (Picea abies) & 36.1124 & 3.5 \\
\hline 10 & - the secondary forest communities with domination of birch tree (Betula pendula) & 29.0520 & 2.8 \\
\hline 11 & - the secondary forest communities with domination of oak (Quercus robur) & 43.9932 & 4.2 \\
\hline 12 & - the secondary forest communities with domination of hornbeam (Carpinus betulus) & 1.6982 & 0.2 \\
\hline 13 & - the secondary forest communities with domination of aspen (Populus tremula) & 0.3044 & 0.03 \\
\hline 16 & - the secondary forest communities with domination of alder (Alnus glutinosa) & 12.7935 & 1.2 \\
\hline 17 & - the secondary forest communities with domination of ash tree (Fraxinus excelsior) & 0.4224 & 0.04 \\
\hline 19 & - the secondary forest communities with domination of linden (Tilia cordata) & 0.0527 & 0.01 \\
\hline \multicolumn{2}{|r|}{ TOTAL } & 1041.8386 & 100 \\
\hline
\end{tabular}

* The forest area $\left(\mathrm{km}^{2}\right)$ of the Knyszyńska Forest; seminatural, synanthropic and unidentified vegetations excluded.

** Percent contribution in the area of the Forest; seminatural, synanthropic and unidentified vegetations excluded.

lower (Tab. 5). For example, the young-tree communities with domination of spruce (Picea abies) make only $2.3 \%$, with domination of oak (Quercus robur) $-1.8 \%$ and with domination of birch tree (Betula pendula) - 1\% (Tab. 5).
The observed types of the present-day real vegetation are surprising. It is interesting to find why the pine tree stands dominate in the vertical structure of the majority of the forest communities despite a considerable presence of the potentially fertile oak-hornbeam habitats. The question 
is what are the reasons for the inconsistencies between the species composition and the type of habitats.

The answer to this question was found on the basis of the spatial modelling. Using the method of construction of logical expressions applied to the spatial GIS database the co-occurrence of particular types of the present-day real vegetation was analysed versus the units of the potential natural vegetation (Tab. 6). Particular attention was put to the contribution of the pine tree stands in all habitats studied, both coniferous and oak-hornbeam ones.

\subsection{Correlation of occurrence of the present-day real vegetation with respect to the units of the present-day potential natural vegetation}

As follows from analysis of the spatial relations between the two types of vegetation, within the Knyszynska Forest, the dominant types of the present-day real vegetation are the forest secondary communities in the stickstand type with predominance of pine, irrespective of the potential types of the habitat studied. The pine tree stands make from 70 to $100 \%$ of the studied units of the present-day real vegetation in the structure of forests of all Knyszyńska Forest divisions and districts, in the coniferous habitats of fresh Peucedano-Pinetum and mixed fresh coniferous habitats of Serratulo-Piceetum and Carici digitatae-Piceetum (Tab. 6). However, according to the statistical analyses, pine tree stands are dominant not only in the coniferous habitats but also in the oak-hornbeam habitats. The pine tree stands make from 50 to $94 \%$ of the forest secondary communities in the Knyszyńska Forest divisions and districts, except the districts Kumiałka and Czarna Białostocka in the Czarna Białostocka division in the oak-hornbeam habitats of the mixed fresh forest Melitti-Carpinetum and fresh forest Tilio-Carpinetum (Tab. 6). The pine trees artificially introduced into fertile oak-hornbeam habitats often grow in the form of one-age and one-generation populations of a low capability of natural renewal. This is the reason why in later developmental phases in the upper layers of the tree stand the expansive spruce trees begin to dominate. Consequently, spruce trees (Knyszyn district $1.1322 \mathrm{~km}^{2}$, Zajma district $-0.8315 \mathrm{~km}^{2}$ ) begin to co-occur with the pine trees $\left(3.2146 \mathrm{~km}^{2}, 1.3694 \mathrm{~km}^{2}\right.$, respectively). Sometimes the pine trees (Czarna district - $4.4704 \mathrm{~km}^{2}$, Waliły district $-2.6416 \mathrm{~km}^{2}$ ) are accompanied by the oak trees (Czarna district $-4.2584 \mathrm{~km}^{2}$ ) or birch trees (Waliły district $-1.5331 \mathrm{~km}^{2}$ ). Only in the northern skirts of the Knyszyńska Forest in the Kumiałka district, the oak tree stands $\left(23.5867 \mathrm{~km}^{2}\right)$ are dominant in the forest secondary communities in the typical oak-hornbeam habitats TilioCarpinetum $\left(35.8165 \mathrm{~km}^{2}\right)$.

As follows from the analysis of the spatial relations between the two types of vegetation, the present-state real vegetation in the Knyszyńska Forest is a consequence of the forest management policy. The analysis has shown that besides the pine tree stands dominant in the species composition of forest communities, pine trees have also dominated the younger developmental stage communities (young tree stands). In the forest structure of all divisions and districts the young pine tree communities are the dominant types of real vegetation in the younger developmental stages growing in the coniferous habitats. In the oak-hornbeam habitats the young pine tree communities dominate among the birch, spruce, oak and alder tree stands in the districts Supraśl, Sokółka, Złota Wieś, Knyszyn, Zajma and Żednia (Tab. 6). This concerns in particular the oakhornbeam habitats of the mixed fresh forest Melitti-Carpinetum. Only in the northern fragment of the Knyszyńska Forest in the districts Kumiałka and Czarna Białostocka, the young oak tree communities dominate $\left(2.8160 \mathrm{~km}^{2}\right.$; $6.0063 \mathrm{~km}^{2}$, respectively) among the young tree stands in the oak-hornbeam habitats $\left(5.3189 \mathrm{~km}^{2} ; 8.6972 \mathrm{~km}^{2}\right.$, respectively). In the other districts in the oak-hornbeam habitats the young pine trees accompany the young birch tree stands (districts Krynki, Waliły, Katrynka) or young spruce and oak trees (districts Złota Wieś, Dojlidy) (Tab. 6)

The secondary forest communities and the young tree communities with dominant pine appeared as a consequence of application of the clear-cutting as the most popular forest management measure, not only in the coniferous but also in the oak-hornbeam habitats in which such a measure should not be applied. The clear cutting means that all trees over a given area are cut out and artificial forest crop are introduced. This type of cutting was commonly applied in coniferous habitats and oak-hornbeam habitats in the districts Krynki, Waliły, Knyszyn, Żednia and Sokółka. The partial cutting was applied in oak-hornbeam habitats less frequently, mainly in the districts Złota Wieś, Czarna Białostocka, Katrynka and Zajma. In the other districts (Krynki, Supraśl, Dojlidy), the two types of cutting were applied (Tab. 6).

As follows from the analysis of the spatial GIS data, in the area of the Knyszyńska Forest, the natural communities dominate in the present-day real vegetation only in the habitats of coniferous and deciduous bog forests in all divisions (Tab. 6). The high degree of their natural character is a result of the unique hydrological conditions preventing the use of simple forest management measures like clearcutting.

\subsection{Range of the anthropogenic changes of vegetation in the Knyszyńska Forest}

The final result is determination of the range of anthropogenic changes in the vegetation allowing a determination of the difference between the potential natural vegetation and real vegetation, caused by anthropogenic factors. The post-clear-cutting and forest crops communities, the 
Table 6. Generalization of the data on the correlation of occurrence of the present-day real vegetation (Rosr) with respect to the units of the present-day potential natural vegetation (Rosp) taking into regard the dominant types of the secondary communities

\begin{tabular}{|c|c|c|c|c|c|c|c|c|}
\hline Forest & \multirow{2}{*}{ The real vegetation (Rosr) } & \multicolumn{7}{|c|}{ The present-day potential natural vegetation (Rosp) } \\
\hline \multirow[t]{2}{*}{ Districts } & & $1 *$ & 2 & 3 & 4 & 5 & 6 & 7 \\
\hline & & \multicolumn{7}{|c|}{ The forest area $\left[\mathrm{km}^{2}\right]$} \\
\hline \multirow{10}{*}{ Zlota Wieś } & The natural forest communities & - & - & 0.4644 & 0.7055 & 1.6771 & 0.1329 & 11.8240 \\
\hline & The post-clear-cutting and forest crops & $0.0993 * *$ & 0.1580 & 0.5650 & 0.6459 & 1.8054 & 0.0653 & 1.1955 \\
\hline & - including used clear cutting & 0.0841 & 0.1500 & 0.3757 & 0.2390 & 0.6112 & 0.0653 & 0.5268 \\
\hline & - including used partial cutting & 0.0152 & 0.0080 & 0.1893 & 0.4069 & 1.1942 & - & 0.6687 \\
\hline & The young tree communities, in this: & 0.1960 & - & 4.6806 & 1.8594 & 2.7076 & 0.0742 & 0.0857 \\
\hline & with pine tree (Pinus sylvestris) & 0.1643 & - & 4.2511 & 1.3508 & 0.4881 & 0.0250 & - \\
\hline & with spruce (Picea abies) & 0.0042 & - & 0.1910 & 0.0459 & 0.8397 & - & - \\
\hline & with oak (Quercus robur) & 0.0275 & - & 0.0837 & 0.2390 & 0.8841 & 0.0492 & - \\
\hline & The secondary forest communities, in this: & 2.4677 & 1.7663 & 13.0106 & 10.9960 & 10.5227 & 0.4408 & 0.0381 \\
\hline & with pine tree (Pinus sylvestris) & 2.4614 & 1.54027 & 12.2700 & 9.8061 & 8.1434 & 0.4408 & 0.0102 \\
\hline \multirow{10}{*}{$\begin{array}{c}\text { Czarna } \\
\text { Bialostocka }\end{array}$} & The natural forest communities & - & 0.3508 & - & - & 1.9652 & 0.2159 & 6.9333 \\
\hline & The post-clear-cutting and forest crops & 0.0337 & 0.7499 & 0.2078 & - & 4.2437 & 0.4000 & 1.1809 \\
\hline & - including used clear cutting & 0.0337 & 0.5814 & 0.1062 & - & 1.3843 & 0.2644 & 0.8689 \\
\hline & - including used partial cutting & - & 0.1685 & 0.1015 & - & 2.8594 & 0.1355 & 0.3119 \\
\hline & The young tree communities, in this: & 0.3338 & 1.5493 & 0.4101 & - & 8.6972 & 0.3932 & 0.0056 \\
\hline & with oak (Quercus robur) & - & 0.1489 & 0.1007 & - & 6.0063 & 0.0653 & - \\
\hline & with pine tree (Pinus sylvestris) & 0.3273 & 0.9333 & 0.1944 & - & 0.3432 & 0.2284 & - \\
\hline & The secondary forest communities, in this: & 3.0167 & 12.7393 & 4.1394 & - & 17.5167 & 2.9845 & - \\
\hline & with oak (Quercus robur) & - & 0.1594 & 0.4284 & - & 4.2584 & 0.0293 & - \\
\hline & with pine tree (Pinus sylvestris) & 3.0032 & 11.0435 & 2.9321 & - & 4.4704 & 2.1042 & - \\
\hline \multirow{10}{*}{ Kumiałka } & The natural forest communities & - & 0.0577 & 0.3068 & 1.4222 & 1.3754 & 0.0865 & 1.8885 \\
\hline & The post-clear-cutting and forest crops & - & 0.1036 & 0.5987 & 1.7638 & 1.0928 & 0.4623 & 0.1686 \\
\hline & - including used clear cutting & - & 0.1036 & 0.2788 & 0.5592 & 0.6570 & 0.0836 & 0.1387 \\
\hline & - including used partial cutting & - & - & 0.3198 & 1.2046 & 0.4358 & 0.3787 & 0.0299 \\
\hline & The young tree communities, in this: & - & 2.0174 & 3.0753 & 5.3189 & 5.5566 & 0.8340 & - \\
\hline & with oak (Quercus robur) & - & - & 0.7401 & 2.8160 & 3.7123 & 0.6580 & - \\
\hline & with pine tree (Pinus sylvestris) & - & 2.0174 & 2.1987 & 1.5606 & 1.1351 & 0.0942 & - \\
\hline & The secondary forest communities, in this: & - & 1.0626 & 10.6663 & 24.7000 & 35.8165 & 3.7171 & 0.0324 \\
\hline & with oak (Quercus robur) & - & - & 0.8911 & 6.8594 & 23.5867 & 0.7943 & - \\
\hline & with pine tree (Pinus sylvestris) & - & 0.8242 & 7.8310 & 15.2775 & 6.5755 & 2.1370 & 0.0324 \\
\hline \multirow{8}{*}{ Supraśl } & The natural forest communities & 0.2336 & 1.8006 & 1.6249 & 0.6551 & 0.3991 & 0.2615 & 8.7106 \\
\hline & The post-clear-cutting and forest crops & 0.0781 & 0.6376 & 0.6100 & 0.9028 & 0.5967 & 0.1616 & 0.8260 \\
\hline & - including used clear cutting & 0.0781 & 0.5804 & 0.5499 & 0.6317 & 0.2568 & 0.1149 & 0.1945 \\
\hline & - including used partial cutting & - & 0.0573 & 0.0601 & 0.2711 & 0.3399 & 0.0466 & 0.6315 \\
\hline & The young tree communities, in this: & 0.2946 & 2.9703 & 2.2377 & 2.3965 & 1.4337 & 0.3508 & 0.0091 \\
\hline & with pine tree (Pinus sylvestris) & 0.2946 & 2.6539 & 1.8735 & 1.2571 & 0.4108 & 0.2795 & - \\
\hline & The secondary forest communities, in this: & 1.6026 & 12.1768 & 12.6526 & 12.5255 & 4.4503 & 1.9460 & - \\
\hline & with pine tree (Pinus sylvestris) & 1.5655 & 11.2523 & 11.3117 & 9.6231 & 3.0402 & 1.8339 & - \\
\hline \multirow{8}{*}{ Sokólka } & The natural forest communities & - & 0.5448 & 0.1724 & - & 0.7946 & 0.2618 & 13.1665 \\
\hline & The post-clear-cutting and forest crops & - & 1.2779 & 0.2455 & 0.0424 & 0.8113 & 0.4408 & 0.4033 \\
\hline & - including used clear cutting & - & 1.0930 & 0.0952 & 0.0424 & 0.5878 & 0.1785 & 0.3727 \\
\hline & - including used partial cutting & - & 0.1849 & 0.1503 & - & 0.2236 & 0.2623 & 0.0306 \\
\hline & The young tree communities, in this: & 0.0574 & 2.9073 & 1.8154 & 0.0618 & 3.7765 & 0.9278 & - \\
\hline & with pine tree (Pinus sylvestris) & 0.0574 & 2.3900 & 1.1148 & 0.0312 & 2.5064 & 0.5442 & - \\
\hline & The secondary forest communities, in this: & 0.6864 & 23.0366 & 12.1174 & 2.6976 & 16.6037 & 7.5764 & - \\
\hline & with pine tree (Pinus sylvestris) & 0.6864 & 21.6709 & 11.2125 & 2.1753 & 13.8284 & 6.7430 & - \\
\hline
\end{tabular}




\begin{tabular}{|c|c|c|c|c|c|c|c|c|}
\hline Forest & \multirow{2}{*}{ The real vegetation (Rosr) } & \multicolumn{7}{|c|}{ The present-day potential natural vegetation (Rosp) } \\
\hline \multirow[t]{2}{*}{ Districts } & & $1 *$ & 2 & 3 & 4 & 5 & 6 & 7 \\
\hline & & \multicolumn{7}{|c|}{ The forest area $\left[\mathrm{km}^{2}\right]$} \\
\hline \multirow{10}{*}{ Dojlidy } & The natural forest communities & 0.0932 & 0.9320 & 0.1259 & 0.0748 & 0.6103 & 0.1198 & 3.8391 \\
\hline & The post-clear-cutting and forest crops & 0.3150 & 0.7710 & 0.0318 & 0.2733 & 0.7755 & 0.1529 & 0.3124 \\
\hline & - including used clear cutting & 0.3150 & 0.5895 & 0.0318 & 0.0679 & 0.4542 & 0.1529 & 0.3124 \\
\hline & - including used partial cutting & - & 0.1815 & - & 0.2054 & 0.3213 & - & - \\
\hline & The young tree communities, in this: & 0.3090 & 0.5000 & 0.3828 & 0.2052 & 0.7875 & 0.1730 & - \\
\hline & with pine tree (Pinus sylvestris) & 0.1678 & 0.3851 & 0.1363 & - & 0.0318 & - & - \\
\hline & with spruce (Picea abies) & 0.0615 & 0.0524 & - & 0.0292 & 0.2064 & 0.0911 & - \\
\hline & with oak (Quercus robur) & - & - & 0.1207 & 0.1390 & 0.3547 & - & - \\
\hline & The secondary forest communities, in this: & 11.7545 & 5.7601 & 0.2491 & 1.3555 & 3.6523 & 1.9272 & - \\
\hline & with pine tree (Pinus sylvestris) & 11.5820 & 5.2262 & 0.2491 & 0.7459 & 2.3596 & 1.7710 & - \\
\hline \multirow{9}{*}{ Katrynka } & The natural forest communities & 0.0086 & 0.3901 & 0.1145 & - & - & - & 4.0264 \\
\hline & The post-clear-cutting and forest crops & 0.1800 & 0.4674 & 0.2867 & - & 0.2984 & 0.1814 & 0.1334 \\
\hline & - including used clear cutting & 0.1734 & 0.4085 & 0.2867 & - & 0.1085 & 0.0492 & 0.1334 \\
\hline & - including used partial cutting & 0.0066 & 0.0589 & - & - & 0.1899 & 0.1322 & - \\
\hline & The young tree communities, in this: & 1.4212 & 2.8909 & 0.8735 & - & 1.6727 & 0.0425 & - \\
\hline & with pine tree (Pinus sylvestris) & 1.4041 & 2.7358 & 0.8228 & - & 0.3635 & 0.0425 & - \\
\hline & with birch tree (Betula pendula) & - & - & 0.0290 & - & 1.1837 & - & - \\
\hline & The secondary forest communities, in this: & 13.1860 & 25.0388 & 83.1964 & - & 3.9436 & 2.0754 & 0.0742 \\
\hline & with pine tree (Pinus sylvestris) & 12.9360 & 24.2420 & 82.9328 & - & 2.7085 & 1.8642 & 0.0047 \\
\hline \multirow{9}{*}{ Knyszyn } & The natural forest communities & 0.2263 & 0.3272 & 0.3975 & 0.5716 & 0.6776 & 0.2559 & 10.2432 \\
\hline & The post-clear-cutting and forest crops & 0.0028 & 0.7850 & 0.8054 & 0.2018 & 0.9529 & 0.3946 & 1.0874 \\
\hline & - including used clear cutting & 0.0028 & 0.6295 & - & 0.1775 & 0.7943 & 0.3946 & 1.0874 \\
\hline & - including used partial cutting & - & 0.1555 & - & 0.0243 & 0.1586 & - & - \\
\hline & The young tree communities, in this: & 0.5009 & 1.4748 & 2.4754 & 0.9561 & 0.2123 & 0.6724 & - \\
\hline & with pine tree (Pinus sylvestris) & 0.5009 & 0.8555 & 1.8091 & 0.8403 & 0.0293 & 0.4156 & - \\
\hline & The secondary forest communities, in this: & 2.6331 & 15.3841 & 13.5477 & 5.6032 & 4.9401 & 3.9000 & - \\
\hline & with spruce (Picea abies) & 0.0305 & 1.2203 & 0.2706 & 0.1870 & 1.1322 & 0.5203 & - \\
\hline & with pine tree (Pinus sylvestris) & 2.6026 & 13.8875 & 12.2558 & 5.2500 & 3.2146 & 3.0622 & - \\
\hline \multirow{10}{*}{ Walily } & The natural forest communities & 0.1390 & 1.1424 & 0.1120 & - & 1.7911 & 0.0664 & 4.9085 \\
\hline & The post-clear-cutting and forest crops & 0.1469 & 0.6436 & 0.1586 & - & 0.7485 & 0.0219 & 0.8268 \\
\hline & - including used clear cutting & 0.1469 & 0.4373 & 0.1586 & - & 0.4753 & 0.0219 & 0.6503 \\
\hline & - including used partial cutting & - & 0.2063 & - & - & 0.2732 & - & 0.1765 \\
\hline & The young tree communities, in this: & 1.8969 & 2.3089 & 0.0735 & - & 0.8567 & 0.0495 & 0.0134 \\
\hline & with pine tree (Pinus sylvestris) & 1.8969 & 1.8496 & 0.0418 & - & 0.0962 & - & - \\
\hline & with birch tree (Betula pendula) & - & 0.1358 & 0.0070 & - & 0.3354 & - & - \\
\hline & The secondary forest communities, in this: & 8.8128 & 19.6443 & 2.1551 & - & 5.6877 & 0.2473 & - \\
\hline & with birch tree (Betula pendula) & 0.0086 & 0.5794 & 0.0763 & - & 1.5331 & - & - \\
\hline & with pine tree (Pinus sylvestris) & 8.7889 & 18.8230 & 1.8209 & - & 2.6416 & 0.2473 & - \\
\hline \multirow{9}{*}{ Krynki } & The natural forest communities & 1.1561 & 1.4565 & 0.3751 & - & 0.4601 & 0.0870 & 1.1932 \\
\hline & The post-clear-cutting and forest crops & 0.2863 & 0.4268 & 0.3676 & - & 1.1285 & 0.1157 & 0.2962 \\
\hline & - including used clear cutting & 0.2746 & 0.3528 & 0.2397 & - & 0.8443 & 0.0597 & 0.2962 \\
\hline & - including used partial cutting & 0.0117 & 0.0740 & 0.1279 & - & 0.2842 & 0.0560 & - \\
\hline & The young tree communities, in this: & 0.4790 & 1.7155 & 0.3694 & - & 0.9516 & 0.1101 & - \\
\hline & with pine tree (Pinus sylvestris) & 0.3620 & 1.5327 & 0.2172 & - & 0.1151 & 0.0067 & - \\
\hline & with birch tree (Betula pendula) & 0.0422 & 0.0175 & 0.0820 & - & 0.3729 & 0.0714 & - \\
\hline & The secondary forest communities, in this: & 6.8486 & 14.2413 & 8.9913 & - & 8.6666 & 0.4376 & - \\
\hline & with pine tree (Pinus sylvestris) & 6.8075 & 14.1944 & 8.6545 & - & 6.0152 & 0.3161 & - \\
\hline
\end{tabular}




\begin{tabular}{|c|c|c|c|c|c|c|c|c|}
\hline Forest & \multirow{2}{*}{ The real vegetation (Rosr) } & \multicolumn{7}{|c|}{ The present-day potential natural vegetation (Rosp) } \\
\hline \multirow[t]{2}{*}{ Districts } & & $1 *$ & 2 & 3 & 4 & 5 & 6 & 7 \\
\hline & & \multicolumn{7}{|c|}{ The forest area $\left[\mathrm{km}^{2}\right]$} \\
\hline \multirow{8}{*}{ Żednia } & The natural forest communities & 0.0654 & 0.0496 & - & 0.1468 & 0.1018 & 0.0175 & 4.7324 \\
\hline & The post-clear-cutting and forest crops & 0.5106 & 0.4882 & - & 0.2752 & 0.2539 & 0.2919 & 0.6351 \\
\hline & - including used clear cutting & 0.5106 & 0.4882 & - & 0.2752 & 0.2539 & 0.2659 & 0.6351 \\
\hline & - including used partial cutting & - & - & - & - & - & 0.0259 & - \\
\hline & The young tree communities, in this: & 1.8112 & 2.2907 & - & 0.4691 & 0.0905 & 1.4361 & 0.0146 \\
\hline & with pine tree (Pinus sylvestris) & 1.8112 & 2.0678 & - & 0.4256 & 0.0176 & 1.3269 & - \\
\hline & The secondary forest communities, in this: & 8.1799 & 14.3165 & - & 5.0182 & 1.6634 & 12.3947 & 0.0661 \\
\hline & with pine tree (Pinus sylvestris) & 8.0697 & 13.5856 & - & 4.9327 & 0.9849 & 11.7013 & 0.0661 \\
\hline \multirow{9}{*}{ Zajma } & The natural forest communities & 0.5867 & 3.1506 & 2.3077 & 0.8479 & 1.9289 & 0.2978 & 9.0150 \\
\hline & The post-clear-cutting and forest crops & 0.3388 & 2.3303 & 0.7251 & 0.9156 & 0.8583 & 0.1263 & 0.6274 \\
\hline & - including used clear cutting & 0.3388 & 1.6636 & 0.6442 & 0.4083 & 0.3042 & 0.1140 & 0.3121 \\
\hline & - including used partial cutting & - & 0.6667 & 0.0809 & 0.5073 & 0.5541 & 0.0123 & 0.3153 \\
\hline & The young tree communities, in this: & 3.4197 & 2.5045 & 1.6646 & 0.9086 & 0.5958 & 0.2223 & - \\
\hline & with pine tree (Pinus sylvestris) & 3.1209 & 1.4300 & 1.2969 & 0.5988 & 0.0063 & 0.1802 & - \\
\hline & The secondary forest communities, in this: & 18.3027 & 20.8567 & 9.3534 & 2.4304 & 3.3447 & 3.1255 & - \\
\hline & with spruce (Picea abies) & 0.6310 & 2.1657 & 1.0279 & 0.8315 & 0.4824 & 0.3737 & - \\
\hline & with pine tree (Pinus sylvestris) & 17.2179 & 17.8472 & 7.3426 & 1.3694 & 2.1862 & 2.4143 & - \\
\hline
\end{tabular}

Legend:

* Number of attributes of the spatial database of the present-day potential natural vegetation (Rosp).

1 - Subcontinental East-European pine forest - Peucedano-Pinetum

2 - High coniferous forest - Carici digitatae-Piceetum

3 - Fresh mixed coniferous forest - Serratulo-Piceetum

4 - Thermophilous oak-hornbeam forest - Melitti-Carpinetum

5 - Subcontinentale lowland linden-oak-hornbeam - Tilio-Carpinetum

6 - Wet mixed coniferous forests - Querco-Piceetum, Myceli-Piceetum

7 - Flood plain forests, bog forests, bog-spruce and bog-pine forests

** Area of forest units in $\mathrm{km}^{2}$ to the fourth place after comma, given for easy change of units to ha units.

young-tree communities and forest secondary communities, in which the stable species making previous phytocenoses disappeared, make $10 \%$ in the area $106.02 \mathrm{~km}^{2}$. Young-tree communities and forest secondary communities represent an artificially planted tree stand, where the species composition is in disharmony with the habitat conditions. The young-tree communities (13.5\%) and the forest secondary communities (52\%) of artificial tree stand but of the species composition in harmony with the habitat conditions occupy the area of $142.29 \mathrm{~km}^{2}$ and $547.99 \mathrm{~km}^{2}$, respectively. The forest secondary communities with spontaneous tree-stands $(7.9 \%)$ take only $83.55 \mathrm{~km}^{2}$.

\section{Discussion and conclusions}

In ecology mathematical modelling has no better alternative for explanation and prediction of the natural phenomena. There are simple analytical models solvable by analytical methods along with advanced models solvable by approximate numerical methods known as the simulation or empirical models. In ecology, mathematical mod- elling permits precise prediction of biological phenomena on all levels of organisation i.e. individuals (Gimenez et al. 2007), populations (Wang 2007), communities (Lek et al. 2005), ecosystems (Tews et al. 2006) and landscapes (Gough \& Rushton 2000).

Complex ecological systems and the transformations they undergo can hardly be described without ecological modelling, for which one of the best tools is GIS. The GIS procedures applied in the study permitted multifaceted spatial analyses of vegetation relations thanks to the use of construction of logical expressions. GIS is a system of hardware and software used for storage, retrieval, mapping, and analysis of geographic data (ArcView GIS 1997; Kistowski \& Iwańska 1997; Urbański 1997). Practitioners also regard the total GIS as including the operating personnel and the data that go into the system. Spatial features are stored in a coordinate system (latitude/longitude, state plane, UTM etc.), which references a particular place on the Earth. Descriptive attributes in tabular form are associated with spatial features. Spatial data and associated attributes in the same coordinate system can then be layered together for mapping and analysis. The increasing interest in GIS is 
a consequence of its analytical possibilities based on construction of models of spatial relations and their changes (Aalders 2001; Olenderek et al. 2001; Van der Zee 2001). Rapid development of computation methods and availability of increasing number of GIS software packages have offered a possibility of spatial analyses of vegetation relations. In particular, they permit analysis of anthropogenically induced changes in vegetation caused by forest management measures (Laska \& Hildebrand 2001; Łaska 2006a).

The mathematical modelling with the use of constructions of logical expression employed for the GIS database has facilitated analysis of vegetation changes in the area of the entire Knyszyńska Forest. The application of a number of combinations of logical expressions and the objects studied has permitted construction of many models revealing new information on relations of the co-occurrence of the present-day real and potential vegetation. As follows from our study, the dominant types of real vegetation in the Knyszyńska Forest are secondary forest communities and young-tree communities with pine domination, occupying not only potential coniferous habitats but also oakhornbeam habitats. The pine tree stands make from 70 to $100 \%$ in the coniferous habitats and make from 50 to $94 \%$ in the oak-hornbeam habitats of the studied units of the present-day real vegetation in the structure of forests of all Knyszyńska Forest divisions and districts. The analysis has indicated that the forest management measures should aim at developing effective ways of conservation of plant communities in given geographic space and monitoring changes caused by increasing anthropogenic stress.

\section{Acknowledgements}

This research was supported by a rector's project W/WBiŚ/30/06.

\section{References}

Aalders H. J. G. L., 2001, GIS in practice, [in:] A. Nienartowicz \& M. Kunz (eds.), GIS and remote sensing in studies of landscape structure and functioning, Wydawnictwo UMK, Toruń: 9-25.

ArcView GIS, 1997, ArcView GIS. Geographical Information Systems, ESRI Polska, Warszawa: 373.

Berec L., 2002, Techniques of spatially explicit individualbased models: construction, simulation, and mean-field analysis, Ecological Modelling 150: 55-81.

Corne S. A., Carver S. J., Kunin W. E., Lennon J. J. \& van Hees W. W. S., 2004, Predicting forest attributes in southeast Alaska using artificial neural networks, Forest Science 50: 259-276.
Czerwiński A., 1995, Geobotanika w ochronie środowiska lasów Podlasia i Mazur [Geobotany in protection of forests environment of Podlasie and Mazury], Wydawnictwa Politechniki Białostockiej, Białystok: 345.

Dambacher J. M., Li H. W. \& Rossignol P. A., 2003a, Qualitative predictions in model ecosystems, Ecological Modelling 161: 79-93.

Dambacher J. M., Luh H. K., Li H. W. \& Rossignol P. A., 2003b, Qualitative stability and ambiguity in model ecosystems, The American Naturalist 161: 876-888.

Drouet J. L. \& Pagès L., 2003, GRAAL: a model of GRowth, Architecture and carbon ALlocation during the vegetative phase of the whole maize plant. Model description and parameterisation, Ecological Modelling 165: $147-173$.

Drouet J. L. \& Pagès L., 2007, GRAAL-CN: A model of GRowth, Architecture and ALlocation for Carbon and Nitrogen dynamics within whole plants formalised at the organ level, Ecological Modelling 206: 231-249.

Edgar C. C. B. \& Burk T. E., 2007, Demonstration and verification of a model that generates defoliation patterns in forested landscapes, Ecological Modelling 205: $301-313$.

Esri 1993, Arc Macro Language devolping Arc/Info menus and macros with AML, ESRI, Redlans.

Fath B. D., 2004, Network analysis applied to large-scale cyber-ecosystems, Ecological Modelling 171: 329-337.

Fath B. D., Scharler U., Ulanowicz R. E. \& Hannon B., 2007, Ecological network analysis: network construction, Ecological Modelling 208: 49-55.

Fuentes M., Kittel T. G. F. \& Nychka D., 2006, Sensitivity of ecological models to their climate drivers: statistical ensembles for forcing, Ecological Applications 16: $99-116$.

Gevrey M., Worner S., Kasabov N., Pitt J. \& Giraudel J. L., 2006, Estimating risk of events using SOM models: a case study on invasive species establishment, Ecological Modelling 197: 361-372.

Gimenez O., Rossi V., Choquet R., Dehais C., Doris. B., Varella H., Vila J. P. \& Pradel R., 2007, State-space modelling of data on marked individuals, Ecological Modelling 206: 431-438.

Główny Urząd Statystyczny, Ochrona Środowiska [Central Statistical Office, Nature Protection], 1999, Warszawa: 510.

Gough M. C. \& Rushton S. P., 2000, The application of GIS-modelling to mustelid landscape ecology, Mammal Review 30: 197-216.

Jager H. I. \& King A. K., 2004, Spatial uncertainty and ecological models, Ecosystems 7: 841-847.

Jørgensen S. E. \& Bendoricchio G., 2001, Fundamentals of Ecological Modeling, 3rd ed., Elsevier, Amsterdam: 530 . 
Kazanci C., 2007, EcoNet: A new software for ecological modeling, simulation and network analysis, Ecological Modelling 208: 3-8.

Kistowski M. \& Iwańska M., 1997, Systemy Informacji Geograficznej. Podstawy techniczne i metodyczne [Geographical Information Systems. Technical and methodical basics], Bogucki Wydawnictwo Naukowe, Poznań: 189.

Laughlin D. C. \& Grace J. B., 2006, A multivariate model of plant species richness in forested systems: old-growth montane forests with a long history of fire, Oikos 114: 60-70.

Laughlin D. C. \& Abella S. R., 2007, Abiotic and biotic factors explain independent gradients of plant community composition in ponderosa pine forests, Ecological Modelling 205: 231-240.

Lek S., Scardi M., Verdonschot P., Descy J. P. \& Park Y. S., 2005, Modelling Community Structure in Freshwater Ecosystems, Springer: 518.

Li H. W., Rossignol P. A. \& Castillo G., 2000, Risk analysis of species introductions: insights from qualitative modeling, [in:] R. Claudi \& J. H. Leach (eds.), Nonindigenous Fresh Water Organisms, Vectors, Biology, and Impacts, CRC Press, Boca Raton: 431-447.

Lischke H., Zimmermann N. E., Bolliger J., Rickebusch S. \& Löffler T. J., 2006, TreeMig: a forest-landscape model for simulating spatio-temporal patterns from stand to landscape scale, Ecological Modelling 199: 409-420.

Liu C., Zhang L., Davis C. J., Solomon D. S., Brann T. B. \& Caldwell L. E., 2003, Comparison of neural networks and statistical methods in classification of ecological habitats using FIA data, Forest Science 49: 619-631.

Lundquist J. E. \& Sommerfeld R. A., 2002, Use of Fourier transforms to define landscape scales of analysis for disturbances: a case study of thinned and unthinned forest stands, Landscape Ecology 17: 445-454.

Łaska G., 1999a, Ocena stopnia i zasięgu zniekształceń zbiorowisk leśnych Puszczy Knyszyńskiej [Assessment of the degree and scale of forest community disturbances in the Knyszynska Forest], mskr., Białystok: 178.

Łaska G., 1999b, Dzisiejsza potencjalna roślinność naturalna Puszczy Knyszyńskiej - mapa cyfrowa w skali 1:50000 [Present-day potential natural vegetation - the numerical map in scale 1:500000].

Łaska G., 1999c, Dzisiejsza roślinność rzeczywista Puszczy Knyszyńskiej - mapa cyfrowa w skali 1:50000. [Present-day real vegetation - the numerical map in scale 1:500000].

Łaska G., 1999d, Antropogeniczne przeobrażenia roślinności Puszczy Knyszyńskiej - mapa cyfrowa w skali 1:50000 [Assessment of the degree and scale of anthropogenic disturbances of plant communities in the Knyszynska Forest - the numerical map in scale $1: 500000]$.

Łaska G., 2006a, Plant communities in wetland habitats in the Knyszyńska Forest - present state and anthropogenic transformations in the GIS approach, Polish Journal of Enviromental Studies 15: 207-214.

Łaska G., 2006b, Tendencje dynamiczne zbiorowisk zastępczych w Puszczy Knyszyńskiej [Dynamic tendencies of the secondary communities in the Knyszyńska Forest], Bogucki Wydawnictwo Naukowe, Białystok-Poznań: 500.

Łaska G. \& Hildebrand R., 2001, Geographical Information Systems (GIS) in analysis of vegetation changes in the Knyszyńska Forest, [in:] A. Nienartowicz \& M. Kunz (eds.), GIS and remote sensing in studies of landscape structure and functioning, Wydawnictwo UMK, Toruń: 97-116.

Matuszkiewicz W., 2001, Przewodnik do oznaczania zbiorowisk roślinnych Polski [A guide to determine plant communities of Poland], PWN, Warszawa: 537.

McNeil B. E., Martell R. E. \& Read J. M., 2006, GIS and biogeochemical models for examining the legacy of forest disturbance in the Adirondack Park, NY, USA, Ecological Modelling 195: 281-295.

Nienartowicz A. \& Kunz M., 2001, GIS and remote sensing in studies of landscape structure and functioning, Wydawnictwo UMK, Toruń: 303.

Olenderek H., Mozgawa J. \& Korpetta D., 2001, Polskie leśnictwo w systemach informacji przestrzennej [Geographical Information Systems in Polish forestry], [in:] A. Nienartowicz \& M. Kunz (eds.), GIS and remote sensing in studies of landscape structure and functioning, Wydawnictwo UMK, Toruń: 81-95.

Reed J. M. \& Levine S. H., 2005, A model for behavioural regulation of metapopulation dynamics, Ecological Modelling 183: 411-423.

Reineking B., Veste M., Wissel C. \& Huth A., 2006, Environmental variability and allocation trade-offs maintain species diversity in a process-based model of succulent plant communities, Ecological Modelling 199: $486-504$.

Sakanoue S., 2007, Extended logistic model for growth of single-species populations, Ecological Modelling 205: $159-168$.

Scrinzi G., Marzullo L. \& Galvagni D., 2007, Development of a neural network model to update forest distribution data for managed alpine stands, Ecological Modelling 206: 331-346.

Sturtevant B. R., Gustafson E. J., Li W. \& He H. S., 2004a, Modelling biological disturbance in LANDIS: a model description and demonstration using spruce budworm, Ecological Modelling 180: 153-174.

Sturtevant B. R., Gustafson E. J., Li W. \& He H. S., 2004b, Modelling disturbance and succession in forest land- 
scapes using LANDIS: introduction, Ecological Modelling 180: $1-5$.

Tews J., Esther A., Milton S. J. \& Jeltsch F., 2006, Linking a population model with an ecosystem model: assessing the impact of land use and climate change on savanna shrub cover dynamics, Ecological Modelling 195: 219-228.

Tichit M., Doyen L., Lemel J. Y., Renault O. \& Durant D., 2007, A co-viability model of grazing and bird community management in farmland, Ecological Modelling 206: 277-293.

Ulanowicz R. E., 2004, Quantitative methods for ecological network analysis, Computational Biology and Chemistry 28: 321-339.

Urbański J., 1997, Zrozumieć GIS. Analiza informacji przestrzennej [To understand GIS. Analysis of spatial information], Wydawnictwo Naukowe PWN, Warszawa: 144.
Van der Lee G. E. M., Van der Molen D. T., Van den Boogaard H. F. P. \& Van der Klis H., 2006, Uncertainty analysis of a spatial habitat suitability model and implications for ecological management of water bodies, Landscape Ecology 21: 1019-1032.

Van der Zee D., 2001, GIS and landscape change analysis, [in:] A. Nienartowicz \& M. Kunz (eds.), GIS and remote sensing in studies of landscape structure and functioning, Wydawnictwo UMK, Toruń: 27-38.

Wang G., 2007, On the latent state estimation of nonlinear population dynamics using Bayesian and non-Bayesian state-space models, Ecological Modelling 200: $521-528$.

Wintle B. A., McCarthy M. A., Volinsky C. T. \& Kavanagh R. P., 2003, The use of Bayesian model averaging to better represent uncertainty in ecological models. 